\title{
In vitro establishment of Comanthera curralensis, "sempre viva" native of Chapada Diamantina - Bahia
}

\author{
Estabelecimento in vitro de Comanthera curralensis, "sempre viva", \\ nativa da Chapada Diamantina - Bahia
}

\begin{abstract}
Mara Márcia Sampaio Albuquerque ${ }^{I^{*}}$ Alone Lima Brito ${ }^{I I}$ Andressa Priscila Piancó Santos Lima ${ }^{\mathrm{I}}$ Bruno Freitas Matos Alvim I José Raniere Ferreira de Santana ${ }^{I I}$
\end{abstract}

\section{ABSTRACT}

The goal of the present study was to evaluate the germination, initial growth, and in vitro co-cultivation of Comanthera curralensis Moldenke, a "sempre viva" native of the Chapada Diamantina state of Bahia. Full strength (MS) and half-strength MS (MS $1 / 2)$ growth media supplemented with two different sucrose concentrations (15 and $\left.30 \mathrm{~g} \mathrm{~L}^{-1}\right)$ were tested for germination and initial plant growth. Three different plant densities were tested by in vitro culture $(8,10$ and 12 plants per container). MS $1 / 2$ medium with $15 \mathrm{~g} \mathrm{~L}^{-1}$ sucrose resulted in a higher percentage of germination and plant growth for the in vitro establishment of $\boldsymbol{C}$. curralensis. The use of 12 plants per container is indicated for cost reduction in C. curralensis in vitro production.

Key words: Eriocaulaceae, tissue culture, germination, in vitro growth, co-cultivation.

\section{RESUMO}

Este trabalho teve como objetivo avaliar a germinação, o crescimento inicial e o co-cultivo in vitro de Comanthera curralensis Moldenke, uma "sempre viva" nativa da Chapada Diamantina-BA. Para germinação e crescimento inicial, foram testados os meios de cultura MS completo e MS $1 / 2$ suplementados com duas concentrações de sacarose (15 e 30gL $L^{-1}$ ); no cultivo in vitro, foram testadas três quantidades de plantas por recipiente (8,10 e 12). A utilização do meio $\mathrm{MS}^{1 / 2} \mathrm{com} 15 \mathrm{gL}^{-1}$ de sacarose proporcionou maiores porcentagem de germinação crescimento das plantas no estabelecimento in vitro de $\boldsymbol{C}$. curralensis, e o uso de 12 plantas por recipiente é indicado para a redução de custos na produção in vitro da espécie.

Palavras-chave: Eriocaulaceae, cultura de tecidos, germinação, crescimento in vitro, co-cultivo.

\section{INTRODUCTION}

Comanthera curralensis Moldenke is an economically important "sempre viva" species from the region known as Tabuleiro dos Tigres, a municipality of Morro do Chapéu, state of Bahia (BA) (CERQUEIRA et al., 2008). Its use is entirely based on unorganized extractivism, which has put the species at risk of extinction (GIULIETTI \& PIRANI, 1988). Despite its importance, there are no reports of propagation and germplasm conservation methods for $\boldsymbol{C}$. curralensis, which limits the possibilities for commercial use and conservation.

Micropropagation has been reported as an option for the production of "sempre viva" Comanthera mucugensis subsp. mucugensis (PAIXÃO-SANTOS et al., 2003; SILVA, et al., 2005; PAIXÃO-SANTOS et al., 2008; LIMA-BRITO et al., 2011a-b; SANTOS et al., 2006) and Comanthera elegantulus (PÊGO et al., 2013).

The tissue culture method of micropropagation has produced the greatest impact on plant production. It allows large scale plant multiplication within short periods of time using a limited physical space during any season of the year (LIMA-BRITO et al., 2011a-b; PINTO et al., 2011).

In vitro establishment involves determining the type of explant with the greatest capacity to adapt to laboratory conditions (GRATTAPAGLIA \&

\footnotetext{
IPrograma de Pós-graduação em Recursos Genéticos Vegetais, Universidade Estadual de Feira de Santana (UEFS), Av. Transnordestina, s/n, Novo Horizonte, 44036-900, Feira de Santana, BA, Brasil. E-mail: maramarcia_uefs@yahoo.com.br. "Corresponding author

${ }^{I I}$ Departamento de Ciências Biológicas, Universidade Estadual de Feira de Santana (UEFS), Feira de Santana, BA, Brasil. 
MACHADO, 1998). Using seeds as explants guarantees the maintenance of genetic variability avoids the removal of individuals from nature (BELLINTANI et al., 2007).

Decreasing the sucrose and salt concentrations of MS culture medium (MURASHIGE \& SKOOG, 1962) has been reported to improve plant development of several species, in addition to decreasing plant production costs (GEORGE \& SHERRINGTON, 1984; HOFFMANN, 1999). Using a large number of plants per container (cocultivation) allows serial multiplication of plants while reducing costs for culture medium and plant regulators (SOARES et al., 2008).

The goal of the present study was to evaluate the effects of different salt and sucrose concentrations in MS medium and the number of plants per container on the germination and in vitro growth of $\boldsymbol{C}$. curralensis. This is the first study describing the in vitro establishment of $\boldsymbol{C}$. curralensis.

\section{MATERIALS AND METHODS}

Experiment I: Effect of sucrose and salt concentrations in MS medium on the germination and initial growth of Comanthera curralensis

C. curralensis seeds, collected in the surroundings of the city of Morro do Chapéu, BA, were surface sterilized with $70 \%$ alcohol for 1 minute and $2.5 \%$ sodium hypochlorite for 10 minutes, washed four times with autoclaved distilled water, and sown in containers $(250 \mathrm{ml})$ with $60 \mathrm{ml}$ of $\mathrm{MS}$ or $\mathrm{MS} 1 / 2$ culture medium. The culture media was supplemented with 15 or $30 \mathrm{~g} \mathrm{~L}^{-1}$ sucrose and solidified with $7 \mathrm{~g} \mathrm{~L}^{-1}$ agar.

A completely randomized experimental design with a $2 \times 2$ factorial scheme (culture medium salt concentrations $\mathrm{x}$ sucrose concentrations), 10 replicates per treatment, and two samples per replicate was used. Each sample consisted of a container with 30 seeds.

Germination was evaluated daily, and seeds showing primordial leaf, visible to the naked eye, were considered germinated. After 63 days, the following parameters were quantified: germinability $(\% \mathrm{G})$, average germination time (AGT), germination speed index (GSI), and the uniformity of germination coefficient (UGC) (SANTANA \& RANAL, 2000).

Initial plant growth was evaluated 90 days following the beginning of seed germination. The following parameters were quantified: percent plant survival, leaf color, number of leaves and roots, length of the largest leaf and root, and amount of plant fresh and dry matter. The leaf color was analyzed using a scale of 0 to $4: 0=$ grayish; $1=$ yellowish; $2=$ light green; 3 = green; and $4=$ dark green.
Experiment II: In vitro co-cultivation of Comanthera curralensis

Plants germinated in vitro that were 120 days old and measured approximately $3 \mathrm{~cm}$ were inoculated in containers $(250 \mathrm{ml})$ with $60 \mathrm{ml}$ of $\mathrm{MS}^{1} / 2$ culture medium supplemented with $15 \mathrm{~g} \mathrm{~L}^{-1}$ sucrose and solidified with $7 \mathrm{~g} \mathrm{~L}^{-1}$ agar.

Three plant densities were tested: 8,10 , and 12 plants per container. The experimental design was completely randomized (CRD), with 10 replicates per treatment and 4 samples per replicate. Each sample consisted of one container.

Ninety days after inoculation, the following parameters were quantified: percent plant survival, length of the largest leaf and root, and amount of plant fresh and dry matter.

Culture conditions

For all experiments, the $\mathrm{pH}$ of the medium was adjusted to 5.7 before autoclaving at $120^{\circ} \mathrm{C}$ for 15 minutes. Cultures were maintained in a growth chamber at $24 \pm 3^{\circ} \mathrm{C}$ with a $16 \mathrm{~h}$ photoperiod and $60 \mu \mathrm{mol} \mathrm{m} \mathrm{m}^{-2} \mathrm{~s}^{-1}$ of photo synthetically active radiation.

\section{Statistical analysis}

ANOVA followed by Turkey's test was used to determine significant differences between treatments. Values of $\mathrm{P}<0.01$ and $\mathrm{P}<0.05$ were considered statistically significant. SISVAR 5.3 software (FERREIRA, 2003) was used for the statistical analyses.

\section{RESULTS AND DISCUSSION}

A significant interaction effect of salt and sucrose concentrations in the culture medium on $\boldsymbol{C}$. curralensis germinability was observed $(\mathrm{P} \leq 0.05)$ (Table 1). The greatest germinability was observed

Table 1 - Seed germinability $(\% \mathrm{G})$ of Comanthera curralensis as a function of salt and sucrose concentrations in MS culture medium.

\begin{tabular}{lcc}
\hline \multirow{2}{*}{ Salt concentration } & \multicolumn{2}{c}{------Sucrose concentration $\left(\mathrm{g} \mathrm{L}^{-1}\right)------$} \\
& 15 & 30 \\
\hline $\mathrm{MS}^{1} / 2$ & $62.75 \mathrm{~A} \mathrm{a}$ & $55.75 \mathrm{~A} \mathrm{a}$ \\
$\mathrm{MS}$ & $61.67 \mathrm{~A} \mathrm{a}$ & $25.25 \mathrm{~B} \mathrm{~b}$ \\
\hline
\end{tabular}

*Means followed by the same upper case letter in the columns and the same lower case letter in the rows were not significantly different according to Tukey's test at a significance level of $\mathrm{P}<0.05$. 
with the MS $1 / 2$ medium, independent of the sucrose concentration. These results are in agreement with PÊGO et al. (2013), who observed lower germinability of Syngonanthus elegantulus seeds with higher salt concentrations in MS medium.

The sucrose concentration in the medium significantly affected the GSI and AGT $(\mathrm{P} \leq 0.05)$, independent of the salt concentration. The uniformity of germination coefficient (UGC) was not affected by any of the factors analyzed (Table 2).

Seeds sown with $30 \mathrm{~g} \mathrm{~L}^{-1}$ of sucrose exhibited a lower GSI and a higher AGT than those sown with $15 \mathrm{~g} \mathrm{~L}^{-1}$ (Table 2). This finding was likely related to the lower water potential of the medium as a function of the higher concentration of osmotically active compounds, which interfered with water availability for seed germination (TAIZ \& ZEIGER, 2008). MS $1 / 2$ supplemented with $15 \mathrm{~g} \mathrm{~L}^{-1}$ was therefore the most efficient medium for in vitro germination of $\boldsymbol{C}$. curralensis seeds.

Regarding the analysis of initial plant growth, a significant interaction effect of salt and sucrose concentration was observed on the percent survival $(P \leq 0.01)$, leaf color $(P \leq 0.01)$, number of leaves $(\mathrm{P} \leq 0.05)$, length of the largest leaf $(\mathrm{P} \leq 0.01)$, number of roots $(\mathrm{P} \leq 0.05)$, and length of the largest $\operatorname{root}(\mathrm{P} \leq 0.05)$ (Table 3$)$.

Higher means for percent survival, leaf color, number of leaves, and length of the largest leaf were observed with MS $1 / 2$ independent of the sucrose concentration in the medium (Table 3 ). These results are consistent with those of PEGO et al. (2013) and SANTOS et al. (2006), who observed that decreasing the salt concentration in the culture medium positively affected the in vitro growth of Syngonanthus elegantulus and Comanthera mucugensis. This result is likely due to the adaptation of "sempre viva" to shallow and

Table 2 - Influence of sucrose concentrations in the culture medium on in vitro germination speed index (GSI), average germination time (AGT), and uniformity of the germination coefficient (UGC) for seeds of Comanthera curralensis.

\begin{tabular}{lccc}
\hline Sucrose $\left(\mathrm{g} \cdot \mathrm{L}^{-1}\right)$ & GSI & AGT & UGC \\
\hline 15 & $0.037 \mathrm{~A}$ & $27.39 \mathrm{~B}$ & $0.032^{\text {ns }}$ \\
30 & $0.033 \mathrm{~B}$ & $30.39 \mathrm{~A}$ & $0.574^{\mathrm{ns}}$ \\
\hline
\end{tabular}

${ }^{*}$ Means followed by the same letter in the columns were not significantly different according to Tukey's test at a significance level of $\mathrm{P}<0.05$
Table 3 - Effect of sucrose and salt concentrations in MS medium on the in vitro growth of Comanthera curralensis at 90 days in culture.

\begin{tabular}{|c|c|c|}
\hline \multirow[b]{2}{*}{ Salt concentration } & \multicolumn{2}{|c|}{-----Sucrose $\left(g \cdot L^{-1}\right)--$} \\
\hline & 15 & 30 \\
\hline $\mathrm{MS} 1 / 2$ & $42.45 \mathrm{~A} \mathrm{a}$ & $34.25 \mathrm{~A} \mathrm{a}$ \\
\hline MS & $1.67 \mathrm{~B} \mathrm{~b}$ & $0.00 \mathrm{~B} \mathrm{~b}$ \\
\hline \multicolumn{3}{|c|}{ 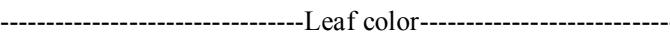 } \\
\hline $\mathrm{MS}^{1} / 2$ & $4.00 \mathrm{~A} \mathrm{a}$ & $3.90 \mathrm{~A} \mathrm{a}$ \\
\hline MS & $1.00 \mathrm{~A} \mathrm{~b}$ & $0.00 \mathrm{~B} \mathrm{c}$ \\
\hline \multicolumn{3}{|c|}{ - } \\
\hline $\mathrm{MS}^{1} / 2$ & $5.37 \mathrm{~A} \mathrm{a}$ & $5.41 \mathrm{~A} \mathrm{a}$ \\
\hline MS & $3.00 \mathrm{~B} \mathrm{a}$ & $0.00 \mathrm{~B} \mathrm{~b}$ \\
\hline \multicolumn{3}{|c|}{ 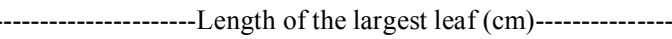 } \\
\hline $\mathrm{MS}^{1} / 2$ & $0.85 \mathrm{~A} \mathrm{a}$ & $0.94 \mathrm{~A} \mathrm{a}$ \\
\hline MS & $0.33 \mathrm{~B} \mathrm{a}$ & $0.00 \mathrm{~B} \mathrm{~b}$ \\
\hline \multicolumn{3}{|c|}{ - } \\
\hline $\mathrm{MS} 1 / 2$ & $0.86 \mathrm{~A} \mathrm{~b}$ & $1.65 \mathrm{~A} \mathrm{a}$ \\
\hline MS & $1.30 \mathrm{~A} \mathrm{a}$ & $0.00 \mathrm{~B} \mathrm{a}$ \\
\hline \multicolumn{3}{|c|}{ - } \\
\hline $\mathrm{MS} 1 / 2$ & $0.08 \mathrm{~A} \mathrm{~b}$ & $0.61 \mathrm{~A} \mathrm{a}$ \\
\hline MS & $0.10 \mathrm{~A} \mathrm{a}$ & $0.00 \mathrm{~B} \mathrm{a}$ \\
\hline
\end{tabular}

*Means followed by the same upper case letter in the columns and lower case letter in the rows were not significantly different according to Tukey's test at a significance level of $\mathrm{P}<0.05$.

poor soils, which are characteristic of the rupestrian fields where they are found.

The greatest root number (1.65) and length $(0.61 \mathrm{~cm})$ were observed with $\mathrm{MS}^{1} / 2$ medium supplemented with $30 \mathrm{~g} \mathrm{~L}^{-1}$ sucrose (Table 3). These results are consistent with those of SANTOS et al. (2006), who observed longer root length for $\boldsymbol{C}$. mucugensis with lower MS medium salt concentration. Use of a higher sucrose concentration resulted in a higher mean root number (1.65) and length $(0.61 \mathrm{~cm})$ (Table 3$)$.

The amount of fresh matter was affected by the salt concentration $(\mathrm{P} \leq 0.05)$ and was greater with the MS $1 / 2$ medium. These results are consistent with those of PINTO et al. (2011), who observed greater fresh matter with lower salt concentrations for in vitro culturing of Mentha arvensis, independent of the sucrose concentration in the medium. In contrast, PÊGO et al. (2013) observed significant differences in fresh matter of Syngonanthus elegantulus at different sucrose concentrations, and the highest means were observed at $30 \mathrm{~g} \mathrm{~L}^{-1}$ sucrose. 
No significant effects in any of the factors analyzed were observed in the amount of plant dry matter (Table 4). The use of $\mathrm{MS}^{1} 12$ medium supplemented with $15 \mathrm{~g} \mathrm{~L}^{-1}$ sucrose for in vitro culture of $\boldsymbol{C}$. curralensis is suggested to improve plant development and decrease plant production costs. Plant density (number of explants per container) significantly affected the amount of plant dry matter $(\mathrm{P} \leq 0.01)$ and the percent survival $(\mathrm{P} \leq 0.05)$. No significant differences were observed in shoot and root length and amount of plant fresh matter (Table 5).

No differences in shoot length were observed. However, the greatest mean amount of plant dry matter was observed with 12 plants per container, although it was not significantly different from the treatment with 10 plants (Table 5).

This finding is not consistent with RODRIGUES et al. (2008), who observed longer shoot length with lower plant density (3 plants per container) for in vitro cultures of Cattleya loddigesii. According to the authors, this result may have been due to competition for nutrients between treatments. C. Curralensis plants may therefore compete less for nutrients in culture medium than other species.

The percent survival was significantly higher at the highest plant density $(88.89 \%)$ (Table 5). This finding suggests possible synergy between plants in vitro, which should be further investigated in future studies. The use of 12 plants per container; therefore, results in lower costs and optimization of in vitro culture of $\boldsymbol{C}$. curralensis.

\section{CONCLUSION}

The use of $\mathrm{MS}^{1} / 2$ medium with $15 \mathrm{~g} \mathrm{~L}^{-1}$ sucroseis suggested for in vitro establishment of $\boldsymbol{C}$. curralensis, and the use of 12 plants per container is suggested for in vitro production of this species.

Table 4 - Fresh (FM) and dry (DM) matter of Comanthera. Curralensis plants grown in vitro in MS culture medium with different saltconcentrations.

\begin{tabular}{lcc}
\hline Salt concentration & FM (mg) & DM (mg) \\
\hline $\mathrm{MS}^{1} / 2$ & $5.6 \mathrm{~A}$ & $0.5^{\mathrm{ns}}$ \\
$\mathrm{MS}$ & $1.8 \mathrm{~B}$ & $0.3^{\mathrm{ns}}$ \\
\hline
\end{tabular}

*Means followed by the same letter in the columns were not significantly different according to Tukey's test at a significance level of $\mathrm{P}<0.05$.
Table 5 - Shoot (SL) and root (RL) length, plant fresh (FM) and dry (DM) matter, and percent survival (\% S) of Comanthera curralensis plants grown in vitro at different plant densities (number of plants per container).

\begin{tabular}{lccllc}
\hline Plant density & SL $(\mathrm{cm})$ & RL $(\mathrm{cm})$ & FM $(\mathrm{g})$ & $\mathrm{DM}(\mathrm{g})$ & $\% \mathrm{~S}$ \\
\hline 8 & $3.85^{\mathrm{ns}}$ & $0.68^{\mathrm{ns}}$ & $1.61^{\mathrm{ns}}$ & $0.16 \mathrm{~B}$ & $45.00 \mathrm{C}$ \\
10 & $4.41^{\mathrm{ns}}$ & $0.88^{\mathrm{ns}}$ & $1.71^{\mathrm{ns}}$ & $0.27 \mathrm{AB}$ & $68.57 \mathrm{~B}$ \\
12 & $4.60^{\text {ns }}$ & $0.94^{\mathrm{ns}}$ & $1.72^{\text {ns }}$ & $0.38 \mathrm{~A}$ & $88.89 \mathrm{~A}$ \\
\hline
\end{tabular}

*Means followed by the same letter in the columns were not significantly different according to Tukey's test at a significance level of $\mathrm{P}<0.05$.

\section{ACKNOWLEDGEMENTS}

The authors thank the Fundação de Amparo à Pesquisa do Estados da Bahia (FAPESB) for financial support through grants and Master Scientific Initiation granted.

\section{REFERENCES}

BELLINTANI, M.C. et al. In vitro establishment of Orthophytum mucugense and Neoregelia mucugensis, endemic bromeliads in the Chapada Diamantina, Bahia - Brazil. Revista Brasileira de Biociências, Porto Alegre, v.5, n.2, p.1101-1103, 2007. Available from: <http://www.ufrgs.br/seerbio/ojs/index.php/ rbb/article/view/872/719>. Accessed: May 15, 2012.

CERQUEIRA, C.O. et al. Fenologia de Syngonanthus mucugensis Giul. subsp. mucugensis e $\boldsymbol{S}$. curralensis Moldenke (Eriocaulaceae), nos municípios de Mucugê e Morro do Chapéu, Chapada Diamantina, BA, Brasil. Acta Botanica Brasilica, Belo Horizonte, v.22, n.4, p.962-969, 2008. Available from: <http:// dx.doi.org/10.1590/S0102-33062008000400007>. Accessed: Apr. 10, 2012. doi: 10.1590/S0102-33062008000400007.

FERREIRA, D.F. SISVAR: Sistema de Análises Estatísticas. Lavras: UFLA, 2003. V.3.4.

GEORGE, E.F.; SHERRINGTON, P.D. Plant propagation by tissue culture. Eversley: Exegetics, 1984. 709p.

GIULIETTI, A.M.; PIRANI, J.R. Patterns of geographic distribution of some plant species from the Espinhaço Range, Minas Gerais and Bahia. In: HEYER, W.R.;VANZOLINI, P.E. PROCEEDINGS OF A WORKSHOP ON NEOTROPICAL DISTRIBUTION PATTERNS. Academia Brasileira de Ciências, p.39-69, 1988.

GRATTAPAGLIA, D.; MACHADO, M.A.Micropropagação. In: TORRES, A.C. et al. (Eds.). Cultura de tecidos e transformação genética de plantas. Brasília, DF: Embrapa-SPI/Embrapa-CNPH. 1998. p.183-260.

HOFFMANN, A. Enraizamento e aclimatização de mudas micropropagadas dos porta-enxertos de macieira 'Marubakaido' e 'M-26'.1999. 240f. Thesis (Ph.D. in Crop Science) - UFL, Lavras, MG. 
LIMA-BRITO, A. et al. In vitro morphogenesis of Syngonanthus mucugensis Giul. Subsp. mucugensis. Revista Ciência e Agrotecnologia, Lavras, v.35, n.3, p.502-510, 2011a. Available from: < http://dx.doi.org/10.1590/S1413-70542011000300010>. Accessed: Feb. 04, 2012. doi: 10.1590/S1413-70542011000300010.

LIMA-BRITO, A. et al. Agentes osmóticos etemperatura na conservação in vitro de sempre-viva. Ciência Rural, Santa Maria, v.41, n.8, p.1354-1361, 2011b. Available from: <http://dx.doi. org/10.1590/S0103-84782011000800010>. Accessed: Feb. 04, 2012. doi: $10.1590 / \mathrm{S} 0103-84782011000800010$.

MURASHIGE, T.; SKOOG, F. A revised medium for rapid growth and bio assays with tobacco tissue cultures. Physiology Plant, Lancaster, v.15, p.473-497, 1962. Available from: <http:// onlinelibrary.wiley.com/doi/10.1111/ppl.1962.15.issue-3/ issuetoc $>$. Accessed: Feb. 01, 2012. doi: 10.1111/j.13993054.1962.tb08052.x.

PAIXÃO-SANTOS, J. et al. Germinação in vitro de Syngonanthus mucugensis Giulietti. Sitientibus Série Ciências Biológicas, Feira de Santana, v.3, n.1, p.120-124, 2003. Available from: $<$ http://www2. uefs.br/revistabiologia/pg3_n1_2.html>. Accessed: Apr. 12, 2012.

PAIXÃO-SANTOS, J. et al. Indução de calos em sempre-viva (Syngonanthus mucugensis Giulietti), utilizando diferentes tipos de explantes e concentrações de BAP. Acta Scientiarum Biological Sciences, Maringá, v.30, n.2, p.127-131, 2008.

PÊGO, R.G. et al. Micropropagation of Syngonanthus elegantulus. Ciência e Agrotecnologia, Lavras, v.37, n.1, p.3239, 2013. Available from: <http://dx.doi.org/10.1590/S141370542013000100004>. Accessed: Jun. 29, 2013. doi: 10.1590/ S1413-70542013000100004.

PINTO, J.E.B.P. et al. In vitro growth of Japanese mint using different salt concentration, number and explant type.
Amazonian Journal of Agricultural and Environmental Sciences, Belém, v.54, n.3, p.267-273, 2011. Available from: <http://dx.doi.org/10.4322/rca.2012.022>. Accessed: May 04, 2012. doi: $10.4322 /$ rca.2012.022.

RODRIGUES, J.D. et al. Ácido giberélico e número de explantes na propagação in vitro de Cattleya loddigesii Lindll. Plant Cell Culture and Micropropagation, Lavras, v.3, n.2, p.78-82, 2008. Available from: $<$ http://portais.ufg.br/uploads/241/original_v3n2. pdf\#page=29>. Accessed: May 04, 2012.

SANTANA, D.G. de; RANAL, M.A. Análise estatística na germinação. In: Mini-curso. 51 ${ }^{\circ}$ CONGRESSO NACIONAL DE BOTÂNICA, 31., 2000, Brasília, DF. Mini-curso... Uberlândia: Universidade Federal de Uberlândia, 2012. $(30 / 04 / 2012)$.

SANTOS, P.J. et al. Ajuste do meio MS para o cultivo in vitro de Syngonanthus mucugensis Giulietti, espécie ameaçada de extinção. Sitientibus Série Ciências Biológicas, Feira de Santana, v.6, n.1, p.36-39, 2006. Available from: <http://www2. uefs.br/revistabiologia/pg6_n1.html $>$. Accessed: Jun. 20, 2013.

SILVA, J.R.S. et al. Efeito da sacarose sobre o enraizamento e desenvolvimento in vitro de Syngonanthus mucugensis Giul. Sitientibus Série Ciências Biológicas, Feira de Santana, v.5, n.2, p.56-59, 2005. Available from: <http://www2.uefs.br/ revistabiologia/pg5_n2.html.>. Accessed: Apr. 27, 2012.

SOARES, J. D. R. et al. Crescimento in vitro de orquídeas: quantidade de meio e número de explantes. Revista Ceres, Viçosa, v.55, n.1, p. 049-053, 2008. Available from: <http:// www.ceres.ufv.br/CERES/revistas/V55N001P00808.pdf>. Accessed: May 4, 2012.

TAIZ, L.; ZEIGER, E. Fisiologia vegetal. 4.ed. São Paulo: Artmed, 2008, 820p. 